\title{
Serat Bambu Petung (Dendrocalamus asper) Teralkalisasi sebagai Penguat Komposit Polimer
}

\author{
Gunawan Refiadi*1, Novan Bayu', Hermawan Judawisastra², Mardiyati² \\ ${ }^{1}$ Sekolah Keguruan dan Ilmu Kependidikan (STKIP) 11 April, Jl. Anggrek Situ No. 19 Sumedang, Indonesia \\ ${ }^{2}$ Institut Teknologi Bandung, J1. Ganesha 10 Bandung, Indonesia
}

Diterima : 30 Oktober 2017, Revisi akhir : 03 Mei 2018, Disetujui terbit : 07 Mei 2018

\section{The Alkalized of Petung Bamboo Fiber (Dendrocalamus asper) as Reinforcement of Polymer Composite}

\begin{abstract}
Petung bamboo (Dendrocalamus asper) has good fiber characteristic and it has potential to substitute glass fiber as reinforcement in polymeric composite. However, like other natural based materials, bamboo fiber has a high variability in mechanical properties and inherently hygroscopic characteristic. Therefore it is required to optimize the petung bamboo qualities. The fiber optimization was carried out by alkalization process using $\mathrm{NaOH}$ solution with varying concentration of 0, 3, 5, and 10\% v/v. Bamboo fiber processed in chemo-mechanical was used in this investigation. Characterization of density, mechanical and chemicals was conducted by pycnometry method, tensile strength testing, Fourier Transform Spectroscopy (FTIR) and Scanning Electron Microscopy (SEM). The data variability was analyzed by Weibull distribution. Result indicates that the optimum condition of alkalization process of bamboo fiber using $\mathrm{NaOH}$ solution of 5\% v/v which has fiber diameter of $175.098 \pm$ $58.017 \mathrm{~mm}$, tensile strength of $384 \mathrm{MPa}$, and characteristics strength of $390.5 \mathrm{MPa}$.
\end{abstract}

Keywords: petung bamboo, alkalization, characteristics

\begin{abstract}
Abstrak
Bambu petung memiliki karakteristik serat yang baik sehingga berpotensi sebagai pengganti serat gelas untuk penguat komposit polimer. Namun, seperti umumnya serat alam, serat bambu memiliki variabilitas sifat mekanis tinggi dan sifat higroskopik yang inheren. Oleh karena itu, diperlukan upaya optimalisasi kinerja serat bambu petung. Optimalisasi kinerja serat dilakukan melalui proses alkalisasi dengan variasi larutan $\mathrm{NaOH}$ pada konsentrasi 0, 3, 5, dan 10\% v/v. Serat bambu hasil dari proses kimia-mekanik digunakan dalam penelitian ini. Karakterisasi densitas, sifat mekanik, dan sifat kimia serat masing-masing dilakukan dengan metode piknometri, uji tarik, Fourier Transform Spectroscopy (FTIR), Scanning Electron Microscopy (SEM). Analisis variabilitas data menggunakan distribusi Weibull. Hasil menunjukkan bahwa kondisi optimum alkalisasi serat bambu petung, yaitu menggunakan larutan $\mathrm{NaOH} 5 \% \mathrm{v} / \mathrm{v}$ yang menghasilkan serat berdiameter 175,098 $\pm 58,017 \mathrm{~mm}$, kekuatan tarik $384 \mathrm{MPa}$, dan kekuatan karakteristik 390,5 MPa.
\end{abstract}

Kata kunci: bambu petung, alkalisasi, karakteristik

\section{Pendahuluan}

Konsep komposit hijau muncul sebagai solusi masalah komposit sintetis yang memiliki beberapa kelemahan seperti sulit terurai di alam, pemakaian energi tinggi, polutan lingkungan, dan berdampak negatif bagi kesehatan. Komposit hijau dibentuk oleh matriks hayati seperti Polylactic Acid (PLA), Polyhydroxy Alkanoat (PHA) atau sintetis dengan serat penguat berbasis 
hayati (jute, ramie, bambu, hemp, abaca, dan lainnya) (Hossen, 2011; Misra, 2011). Tren green development saat ini telah membuat serat hayati menjadi fokus utama sebagai penguat komposit polimer. Keunggulan komparatif serat hayati terhadap serat sintetis adalah sifat spesifiknya mirip, non-abrasif, sumber melimpah di alam, minimum dampak negatif bagi kesehatan dan lingkungan, dan bisa diperbaharui (Joshi, S. V., 2004). Hal ini menjadikan serat penguat komposit berbasis petrokimia seperti serat gelas (glass) dan karbon mulai tergeser kedudukannya oleh serat hayati. Rendahnya densitas serat hayati dibanding serat sintetis memberi keuntungan pada komposit hijau dari sisi pemakaian serat alam. Artinya, untuk mendapat kekuatan komposit yang sama, porsi serat hayati yang ramah lingkungan akan lebih besar daripada matriks sintetis yang polutif. Bobot yang ringan menjadikan komposit berpenguat serat hayati lebih kompetitif untuk penghematan energi di sektor automotif.

Bambu merupakan salah satu sumber potensial untuk serat hayati. Jenis bambu di dunia sekitar 1200-1300 spesies dan 11,9\% diantaranya berada di Indonesia (Abdul Khalil et al., 2012). Bambu petung paling banyak ditemukan di pulau Jawa dan Sumatra dengan kisaran diameter seratnya antara 195 361 mm, memiliki rentang kekuatan tarik 114 314 MPa, modulus elastisitas antara 3,2 7 GPa dan regangan 3,3 5,1\% (Viel. Q, 2013). Dalam penelitian Wang et al. (2014) yang dikutip dari Osorio L (2011) menunjukkan bahwa serat bambu memiliki kekuatan yang hampir mirip dengan serat gelas.

Karakterisasi sifat tarik serat pada variasi ketinggian dan kedalaman batang bambu petung (Dendrocalamus asper) telah dilakukan oleh Judawisastra (2016) yang menemukan bahwa kekuatan serat bambu paling tinggi berada di bagian bawah batang dan bagian terluar diameter. Namun, pengukuran densitasnya belum dilakukan dan belum mengarah pada pembuatan komposit hijau. Penelitian terkait bambu petung lainnya telah dilakukan oleh Sugesty, et al. (2014), yang menemukan bahwa kualitas bambu petung adalah yang paling baik diantara jenis bambu lainnya. Namun, penelitian ini ditujukan untuk memperoleh pulp yang tinggi untuk aplikasi pembuatan kertas.

Penelitian komposit hijau (matriks polyester) berpenguat serat bambu petung telah dicapai pada $24 \%$ fraksi volume serat dengan kekuatan tarik arah longitudinal $95 \mathrm{MPa}$ serta modulus elastisitas
$8 \mathrm{GPa}$, dan regangan $4 \%$ yang diperoleh melalui proses hand lay-up (Rosadi, 2017). Berdasarkan hasil ini, Rosadi menyarankan aplikasi metode VARI (Vacuum Assisted Resin Infusion) untuk memperoleh fraksi volume serat yang lebih tinggi. Hal ini didasarkan pada hasil optimasi sistem VARI dengan metode Taguchi pada komposit polyester berpenguat serat E-glass yang telah meningkatkan fraksi volume serat hand layup dari 27,5\% menjadi 54,3\% (Refiadi, 2013). Penelitian komposit hijau oleh Judawisastra (2017) dan komposit sintetis oleh Refiadi (2013) keduanya masih menggunakan matriks polimer polyester dan belum menggunakan epoksi sebagai matriks kompositnya. Penelitian komposit hijau serat bambu-epoksi untuk rompi anti peluru telah membuktikan bahwa serat bambu cukup efisien, ringan, dan lebih ekonomis dibandingkan dengan serat aramid (Cruz, 2015). Nozari et al.,( 2013) melaporkan bahwa serat alam (bubuk kayu) teralkalisasi dapat menurunkan tingkat absorpsi air pada komposit bermatriks LDPE (Low Density Polyethylene).

Alkalisasi dapat memperkecil diameter serat bambu dengan melarutkan lignin dan amorf (Chakraborty, 2015). Hal ini telah dibuktikan dengan peningkatan kekuatan tarik dan elongasi yang signifikan pada komposit yang dihasilkan (Lu et al., 2013). Matriks epoksi terbukti memiliki tingkat pembasahan (wetting) serat dan tingkat adhesi terhadap serat bambu Guadua angustifolia (Vuure, 2013) dan merefleksikan hasil penelitiannya dalam dua kondisi, yaitu 95\% transfer modulus serat longitudinal terhadap modulus komposit bending longitudinal dan $80 \%$ transfer modulus serat longitudinal terhadap kekuatan komposit longitudinal. Berdasarkan hasil studi literatur, penelitian ini mengkaji karakteristik serat bambu petung pada variabel tingkat alkalisasi untuk memperoleh kekuatan tarik serat yang paling optimum untuk dikembangkan menjadi komposit hijau berpenguat serat bambu petung.

\section{Bahan dan Metode}

\section{Bahan}

Bahan utama yang digunakan dalam penelitian ini adalah bagian bawah batang bambu petung berusia 2 tahun yang diperoleh dari Balai Penelitian Bambu, Pasir Impun - Bandung. Larutan untuk proses pembuatan serat bambu, 
yaitu $\mathrm{NaOH} 20 \% \mathrm{v} / \mathrm{v}$ dan $\mathrm{HCl} 2 \% \mathrm{v} / \mathrm{v}$, variasi larutan untuk proses alkalisasi yaitu larutan $\mathrm{NaOH}$ $3 \%, 5 \%$, dan $10 \% \mathrm{v} / \mathrm{v}$. Selanjutnya, larutan $\mathrm{HCl}$ $2 \% \mathrm{v} / \mathrm{v}$ dan aqua $\mathrm{dm}$ digunakan untuk pencucian hasil proses alkalisasi.

\section{Ekstraksi Kimia-Mekanik Serat Bambu Petung}

Proses kimia untuk memperoleh serat dilakukan melalui perendaman bilah bambu dalam larutan $\mathrm{NaOH} 20 \% \mathrm{v} / \mathrm{v}$ pada suhu $27^{\circ} \mathrm{C}$ selama 1 jam. Setelah itu dilakukan pencucian bilah dengan larutan $\mathrm{HCl} 2 \% \mathrm{v} / \mathrm{v}$ dan aqua dm (Judawisastra, 2016; Judawisastra, 2017). Pada Gambar 1(b) diperlihatkan bilah bambu hasil pengeringan memakai tungku (muffle) (Gambar 1a) pada suhu $105^{\circ} \mathrm{C}$ selama 1 jam sebelum diproses secara mekanik pada suhu ruangan menggunakan mesin softening (Gambar 1c) diikuti finishing melalui proses combing menggunakan sisir kawat sampai diperoleh sampel serat bambu (Gambar 1d) untuk selanjutnya, serat dialkalisasi dengan variasi konsentrasi larutan $\mathrm{NaOH}$.

\section{Alkalisasi dan Karakterisasi Serat}

Proses alkalisasi serat bambu petung dilakukan dengan variasi konsentrasi larutan $\mathrm{NaOH} 3 \%$, $5 \%$, dan $10 \% \mathrm{v} / \mathrm{v}$, dan blanko ( $\mathrm{NaOH} 0 \%$ ) sebagai pembanding. Proses alkalisasi dimulai dengan merendam serat bambu hasil ekstraksi pada suhu $25^{\circ} \mathrm{C}$ selama 30 menit. Serat bambu dikeringkan

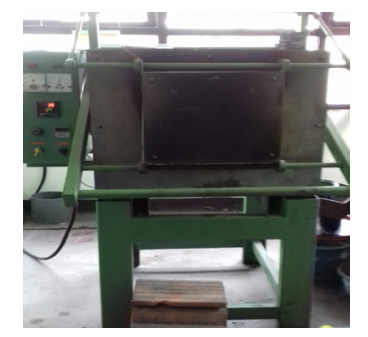

(a)

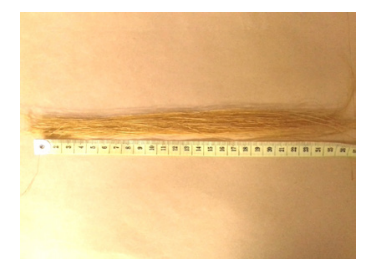

(d)

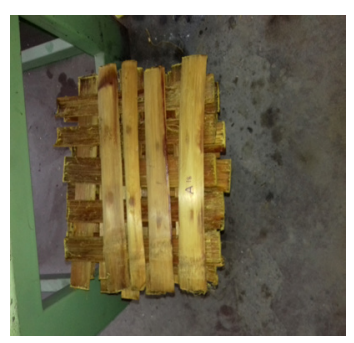

(b)

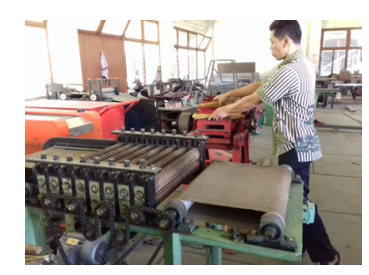

(c)
Gambar 1. Peralatan dan Hasil Ekstraksi Serat Bambu menggunakan Metoda Kimia-Mekanik di dalam oven pada suhu $110^{\circ} \mathrm{C}$ selama 24 jam. Kemudian serat bambu dicuci dengan air destilat dan dinetralkan dengan larutan $\mathrm{HCl} 2 \%$ $\mathrm{v} / \mathrm{v}$. Selanjutnya serat bambu hasil alkalisasi dikarakterisasi sifat fisik, sifat mekanik, dan sifat kimianya di laboratorium metalurgi ITB dan Pusat Survei Geologi Bandung, Balai Besar Tekstil, dan laboratorium kimia analitik ITB.

Karakterisasi sifat fisik meliputi pengamatan morfologi serat melalui pengukuran diameter serat dibawah mikroskop optik dan Scanning Electron Microscope (SEM) JEOL JSM-636OLA dan uji densitas menggunakan metode piknometri ASTM D3171. Sifat mekanik dikarakterisasi melalui uji tarik serat menggunakan mesin Textechno Favigraph sesuai ASTM D3822/3822M-14. Setelah itu serat diuji kekuatan karakteristik, $s_{o}$ dan modulus Weibull nya menggunakan persamaan (1) dan (2). $C$ dan $m$ masing-masing adalah konstanta dan gradien persamaan garis distribusi Weibull. Sifat kimia serat dikarakterisasi dengan metode Fourier Transformation Infra Red (FTIR) Prestige 21 Shimadzu, untuk melihat adanya perubahan gugus fungsi pada permukaan serat setelah proses alkalisasi.

$$
\mathrm{C}=-\mathrm{m} \ln \sigma_{\mathrm{o}}
$$

atau

$\sigma_{\mathrm{o}}=\exp ^{(-\mathrm{C} / \mathrm{m})}$

\section{Hasil dan Pembahasan}

\section{Morfologi dan Densitas Serat}

Hasil karakterisasi morfologi serat pada kondisi blanko dan variasi larutan $\mathrm{NaOH} 3$ $\sim 10 \%$ ditunjukkan pada Tabel 1. Pengaruh perlakuan alkalisasi pada densitas serat bambu petung yang dihasilkan paling tinggi $\left(1,3 \mathrm{~g} / \mathrm{mm}^{3}\right)$ dicapai menggunakan larutan $\mathrm{NaOH} 5 \%$ v/v dengan peningkatan sebesar $24 \%$ dibandingkan blanko. Kontribusi positif alkalisasi terhadap kekuatan tarik serat dikarenakan alkalisasi mengurangi keberadaan hemiselulosa, lignin, wax, garam-garam anorganik dan minyak yang menutupi permukaan serat (Yuan, 2012). Namun pengaruhnya tidak tampak pada serat bambu yang dialkalisasi dengan larutan $\mathrm{NaOH} 10 \% \mathrm{v} / \mathrm{v}$ karena densitas kembali menurun $\left(1,24 \mathrm{~g} / \mathrm{mm}^{3}\right)$. Hal ini dapat diprediksi bahwa persentase alkali 
Tabel 1. Densitas $(\rho)$ dan Diameter Serat (Ø) Bambu Sebelum dan Setelah Perlakuan Alkalisasi

\begin{tabular}{lcccc}
\hline \multirow{2}{*}{ Sample } & \multicolumn{4}{c}{ Konsentrasi larutan $\mathrm{NaOH}$} \\
\cline { 2 - 5 } & $0 \%$ & $3 \%$ & $5 \%$ & $10 \%$ \\
\hline$r\left(\mathrm{~g} / \mathrm{mm}^{3}\right)$ & 1,05 & 1,28 & 1,3 & 1,24 \\
$Æ(\mathrm{~mm})$ & $232 \pm 99$ & $181 \pm 54$ & $175 \pm 58$ & $172 \pm 55$ \\
\hline
\end{tabular}

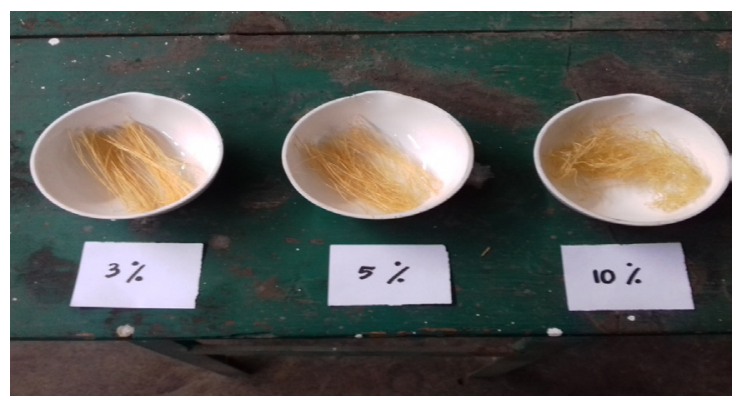

Gambar 2. Perubahan Fisik Serat Bambu pada Tingkat Alkalisasi dengan Larutan $\mathrm{NaOH} 10 \% \mathrm{v} / \mathrm{v}$

mencapai optimum pada larutan $\mathrm{NaOH} 5 \%$ v/v dengan adanya bukti fisik (Gambar 2) berupa rusaknya fisik serat bambu dari berbentuk lurus (Larutan $\mathrm{NaOH} 5 \%$ ) menjadi kusut (larutan $\mathrm{NaOH}$ $10 \%)$. Perlakuan alkalisasi berpengaruh pula pada penurunan diameter serat hingga 26\% (Tabel 1) dan mencapai minimum $(172 \pm 55 \mathrm{~mm})$ pada perlakuan alkali dengan larutan $\mathrm{NaOH} 10 \% \mathrm{v} / \mathrm{v}$.

Visualisasi serat pada spesimen yang sama disajikan pada Gambar 3, di bawah mikroskop optik (a) dan hasil uji SEM (b), yang menampilkan perbedaan morfologi diameter serat bambu petung. Orde diameter serat hasil uji di bawah mikroskop optik yaitu dalam kisaran 145 154 mm sedangkan hasil uji SEM menampilkan ukuran puluhan mikron $(19,5 \mathrm{~mm})$. Hasil penelitian (Lu et al., 2013) menyebutkan bahwa diameter serat dengan orde ratusan mikron termasuk ke dalam kategori bundel serat (fiber bundle), sedangkan orde serat puluhan mikron $(19 \mathrm{~mm})$ untuk serat bambu petung (Dendrocalamus asper) dikategorikan sebagai serat tunggal (ultimate fiber) (Brink, 2008).

Hasil uji diameter serat yang diperoleh dapat menunjukan serat yang dihasilkan melalui metode ekstraksi kimia-mekanik pada penelitian ini adalah berupa bundel serat dan bukan serat tunggal.

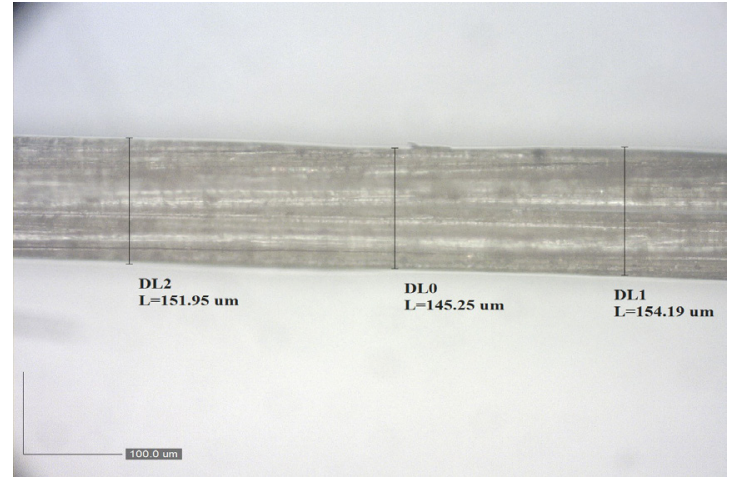

(a)

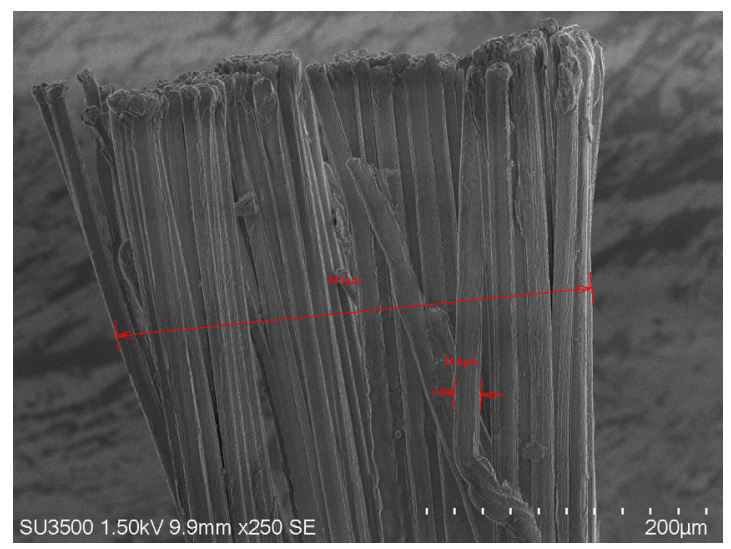

(b)

Gambar 3. Morfologi Bundel dan Serat Tunggal Bambu Petung dibawah Mikroskop Optik (a) dan Hasil Uji SEM (b)

\section{Sifat Mekanik Serat Bambu Petung}

Pada studi ini sifat mekanik serat bambu petung diperoleh melalui hasil pengujian kekuatan tarik $(s)$ dan hasil perhitungan kekuatan karakteristik $(s)$ dan modulus Weibull $(m)$. Kekuatan karakteristik mewakili kekuatan retak pada saat kegagalan serat mulai terjadi dan modulus Weibull mewakili faktor bentuk atau keluasan sebaran data (Trujillo et al., 2012)

Tabel 2 menunjukkan hasil pengujian sifat mekanik serat bambu petung pada variasi komposisi larutan $\mathrm{NaOH}$. Alkalisasi dengan larutan $\mathrm{NaOH} 5 \%$ dapat meningkatkan 55\% kekuatan tarik $(s)$ serat bambu petung dari serat blanko (247 MPa) menjadi $385 \mathrm{MPa}$. Begitu juga kekuatan karakteristik $(s)$ meningkat sebesar $63 \%$ dari blanko (240 MPa) menjadi $391 \mathrm{MPa}$. Kecenderungan ini sejalan dengan hasil penelitian terdahulu (Kessler, 2014; Yousif, 2016; Oushabi et al., 2017),. Wong (2010) melaporkan bahwa 
pada alkalisasi serat bambu dengan larutan $\mathrm{NaOH}$ $5 \% \mathrm{v} / \mathrm{v}$ menunjukkan kinerja terbaiknya dari sisi kekuatan tarik dan modulus elastisitas. Menurut Oushabi (2017), alkalisasi dengan larutan $\mathrm{NaOH}$ $5 \%$ memberikan penguatan sifat mekanik serat hayati hampir $67 \%$, dan serat yang dialkalisasi dengan larutan $\mathrm{NaOH}$ 6\% masih menampilkan kekuatan komposit polyester yang baik (Kumar, 2017).

Pada tingkat alkalisasi dengan larutan $\mathrm{NaOH}$ $10 \% \mathrm{v} / \mathrm{v}$ terjadi penurunan sifat mekanik serat sebesar $36 \%$ dan $28 \%$. Penurunan ini diduga akibat adanya perubahan fisik serat seperti ditunjukkan pada Gambar 2. Hal ini didukung oleh data (Wang, 2017) yang mengonfirmasi bahwa untuk serat bambu, konsentrasi larutan $\mathrm{NaOH} 7 \% \mathrm{v} / \mathrm{v}$ telah memberi efek negatif penghilangan selulosa secara parsial. Hilangnya selulosa yang berpengaruh terhadap kekuatan ini dapat menurunkan kekuatan tarik serat alam. Kerusakan serat dengan penggunaan larutan $\mathrm{NaOH} 10 \%$ ditemukan pula pada hasil penelitian Oushabi (2017).

Rentang kekuatan tarik serat bambu petung yang diperoleh pada penelitian ini, yaitu $246 \sim 385 \mathrm{MPa}$, dapat dikatakan bahwa serat yang diuji merupakan bundel serat. Hal ini sesuai dengan hasil temuan (Ge et al., 2012), yaitu antara $8 \sim 836 \mathrm{MPa}$.

Variabilitas data serat alam dapat ditentukan dengan pola distribusi Weibull (Trujillo et al., 2012). Semakin besar harga modulus Weibull
Tabel 2. Kekuatan Tarik dan Kekuatan Karakteristik Serat Bambu Petung sebelum dan setelah Perlakuan Alkalisasi

\begin{tabular}{lcccc}
\hline \multirow{2}{*}{ Deskripsi } & \multicolumn{4}{c}{ Larutan $\mathrm{NaOH}$} \\
\cline { 2 - 5 } & $0 \%$ & $3 \%$ & $5 \%$ & $10 \%$ \\
\hline$\sigma(\mathrm{MPa})$ & 247 & 268 & 385 & 246 \\
Standar deviasi & 234 & 134 & 379 & 106 \\
$m$ & 1,286 & 2,222 & 1,531 & 2,173 \\
$\sigma_{\mathrm{o}}(\mathrm{MPa})$ & 240 & 312 & 391 & 281 \\
$\mathrm{R}^{2}$ & 0,931 & 0,926 & 0,914 & 0,992 \\
\hline
\end{tabular}

$(m)$, semakin seragam sebaran datanya. Untuk serat sintetis seperti serat gelas harga $m$ berkisar antara $5 \sim 15$ mengindikasikan bahwa diameter seratnya relatif seragam (Defroit, 2010). Gambar 4 menunjukkan tren variabilitas data serat bambu petung sebagai fungsi tingkat alkalisasi. Gradien persamaan garis dengan nilai $m$ berkisar antara $1,3 \sim 2,2$. Rentang nilai $m$ serat bambu ini masih lebih kecil daripada serat hayati secara umum (Defroit, 2010), yaitu antara 1 6, yang berarti bahwa variabilitas data serat bambu petung masih besar. Kondisi ini bisa diakibatkan cacat pada permukaan serat bambu yang disebabkan teknik ekstraksi serat kimia mekanik. Perlakuan alkalisasi dengan larutan $\mathrm{NaOH}$ berpengaruh pada peningkatan linearitas data (nilai $\mathrm{R}^{2}$ ). Gambar 4 menunjukkan bahwa serat dengan perlakukan alkalisasi dengan larutan $\mathrm{NaOH} 10 \% \mathrm{v} / \mathrm{v}\left(\mathrm{R}^{2}=\right.$ $0,992)$ memberikan linearitas data terbaik.

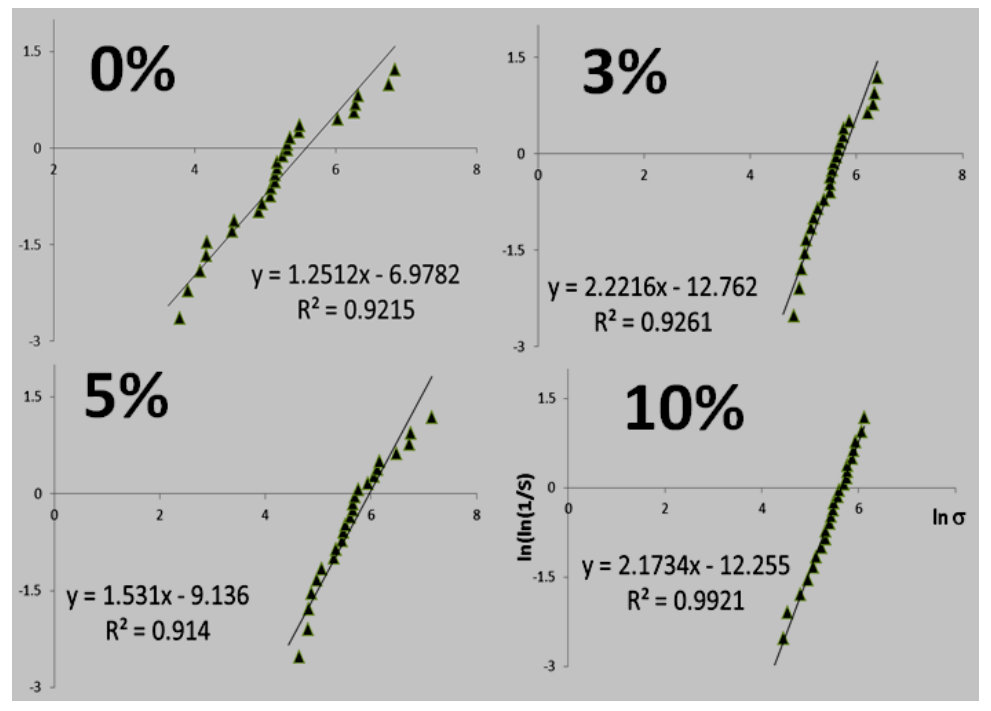

Gambar 4. Nilai Modulus Weibull $(m)$ dengan Variasi Perlakuan Alkalisasi Serat 


\section{Karakterisasi FTIR}

Hasil karakterisasi FTIR (Gambar 5) menunjukkan adanya pengaruh alkalisasi serat terhadap ketinggian peak absorbance pada bilangan gelombang selulosa $\left(896,9 \mathrm{~cm}^{-1}\right)$ (Wong, 2016). Menurut hasil penelitian (Damanik, 2007) modifikasi serat dengan penambahan $\mathrm{NaOH}$ akan menimbulkan gugus fungsi alkoksida $\left(\mathrm{NaO}^{+}\right)$ pada serat selulosa yang asalnya hanya memiliki gugus hidroksil $(\mathrm{OH})$.

Pada Gambar 5 menunjukkan peningkatkan peak absorbance di posisi bilangan gelombang $896 \mathrm{~cm}^{-1}$ seiring kenaikan persentase alkalisasi. Hasil reviu Kalia (2009) menyebutkan bahwa peningkatan ini terkait dengan semakin tingginya nilai kristalinitas serat yang membuat serat semakin kuat dan kaku.

Menurut Peng (2010) perlakuan alkalisasi dapat menurunkan persentase lignin hingga $20 \%$ dan memperbaiki interfacial strength sebagai kontributor peningkatan kekuatan tarik komposit. Alkalisasi juga dapat memperkuat internal bonding strength dan menurunkan hidrofilitas serat bambu sehingga terjadi peningkatan daya ikat antar muka serat - matriks. (Zhang, 2015)melaporkan penurunan hemiselulosa dan lignin berakibat peningkatan selulosa sebagai kontributor kekuatan tarik dan densitas. Alkalisasi juga mengurangi sifat hidrofil serat bambu dan memperbaiki kualitas ikatan antarmuka. Dari perubahan morfologi mikro hasil alkalisasi diperoleh perluasan permukaan serat yang menjadi area interlocking antara serat dengan matriks. Semakin luas area interlocking dari serat hasil alkalisasi akan semakin memperkuat komposit yang dihasilkan.

Hasil temuan di atas seolah kontraproduktif terhadap hasil uji tarik serat (Tabel 2) dimana kekuatan tarik menurun dari $385 \mathrm{MPa}$ (larutan $\mathrm{NaOH} 5 \%$ v/v) menjadi $246 \mathrm{MPa}$ (larutan $\mathrm{NaOH}$ $10 \% \mathrm{v} / \mathrm{v})$ seiring dengan kenaikan persentase konsenrasi $\mathrm{NaOH}$. Hal tersebut dapat dikonfirmasi melalui hasil uji SEM pada serat hasil perlakuan alkalisasi (Gambar 6).

Pada Gambar 6(a) - (d) dapat dilihat bahwa seiring kenaikan konsentrasi larutan $\mathrm{NaOH}$ dari $0 \%$ hingga $10 \%$ terjadi pengurangan lignin di permukaan serat yang ditampilkan melalui morfologi serat tunggal dimana semakin tampak bersih dan jelas. Hal ini sejalan dengan hasil uji tarik serat (Tabel 2) yang meningkatkan kekuatan tarik serat dari $247 \mathrm{MPa}$ (larutan $\mathrm{NaOH} \mathrm{0 \% )} \mathrm{hingga} 385 \mathrm{MPa}$ (larutan $\mathrm{NaOH} 5 \%$ ). Namun pada penggunaan larutan $\mathrm{NaOH} 10 \%$ (d) sebagian serat telah mengalami kerusakan berupa penguraian serat tunggal yang terputus dalam satu sumbu. Hal ini yang menyebabkan penurunan kekuatan tarik serat bambu petung dari $385 \mathrm{MPa}$ (larutan $\mathrm{NaOH} 5 \%$ ) menjadi $246 \mathrm{MPa}$ (larutan $\mathrm{NaOH}$ $10 \%$ ).

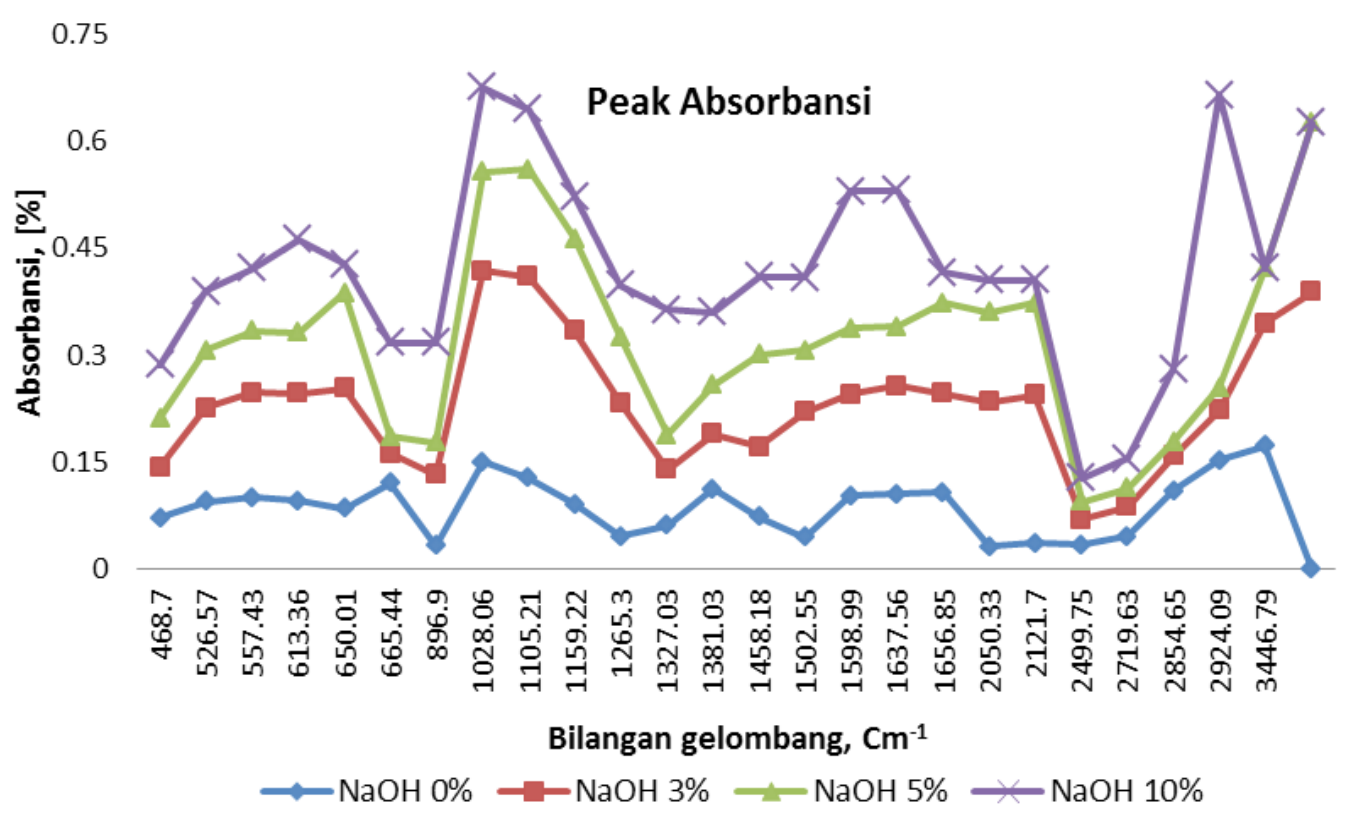

Gambar 5. Pengaruh Alkalisasi Serat terhadap Ketinggian Peak Absorbansi 


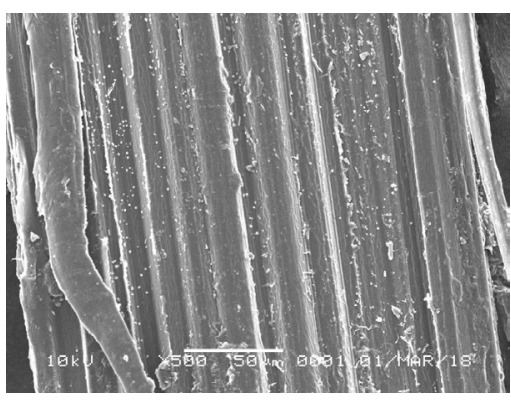

(a) Blanko $(\mathrm{NaOH} 0 \% \mathrm{v} / \mathrm{v})$

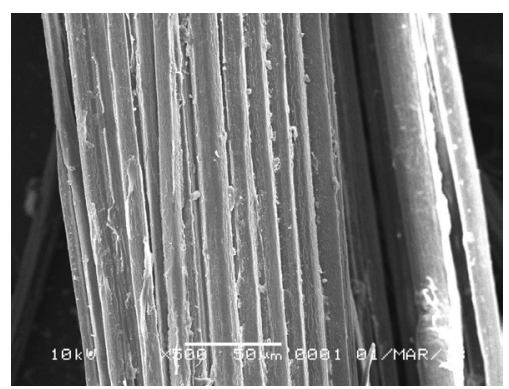

(c) $\mathrm{NaOH} 5 \% \mathrm{v} / \mathrm{v}$

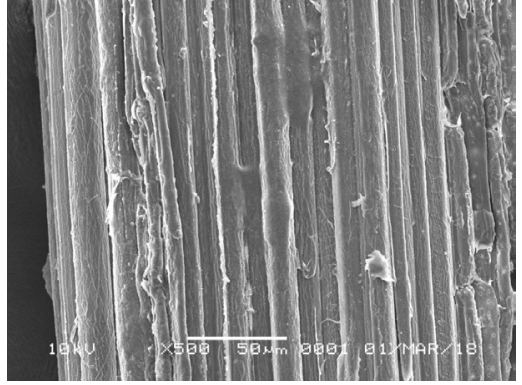

(b) $\mathrm{NaOH} 3 \% \mathrm{v} / \mathrm{v}$

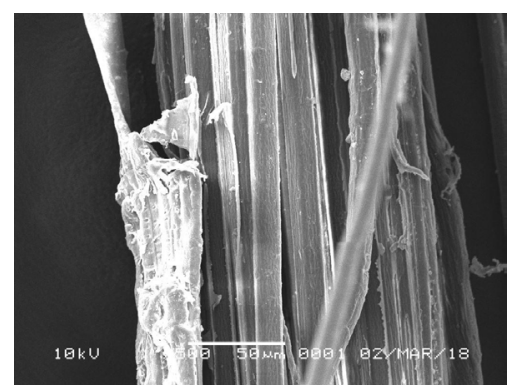

(d) $\mathrm{NaOH} 10 \% \mathrm{v} / \mathrm{v}$

Gambar 6. Morfologi Serat Bambu Petung Hasil Uji SEM Hasil Perlakuan Alkalisasi

\section{Kesimpulan}

Serat bambu petung yang dihasilkan melalui proses ekstraksi dengan metode kimia-mekanik memiliki karakteristik serat yang bervariasi tergantung pada perlakuan alkalisasinya. Berdasarkan hasil karakterisasi diameter serat dan kekuatan tarik, serat bambu yang dihasilkan adalah berupa bundel serat. Berdasarkan capaian kekuatan tariknya, kondisi optimum proses alkalisasi serat bambu petung adalah menggunakan larutan $\mathrm{NaOH}$ $5 \% \mathrm{v} / \mathrm{v}$ yang memiliki kekuatan tarik $384 \mathrm{MPa}$, diameter serat $175,098 \pm 58,017 \mathrm{~mm}$, dan kekuatan karakteristik 390,5 MPa.

\section{Ucapan Terima Kasih}

Penelitian ini terselenggara dengan bantuan dana hibah Penelitian Kerjasama Antar Perguruan Tinggi (PEKERTI) tahun anggaran 2017 yang berasal dari Dirjen Penguatan Riset dan Pengembangan Kemenristekdikti. Untuk itu, kami mengucapkan terima kasih kepada Direktur Riset dan Pengabdian Masyarakat.

\section{Daftar Pustaka}

Abdul Khalil, H. P. S. et al. (2012) 'Bamboo fibre reinforced biocomposites: A review', Materials and Design, pp. 353-368. doi: 10.1016/j.matdes.2012.06.015.
Brink, M. (2008) 'Dendrocalamus asper PROTA database - PlantUse.pdf'. PROTA Network Office Europe, pp. 1-34.

Cruz, J. M. (2015) 'Giant Bamboo Fiber ReinforcedEpoxy Composite in Multilayered Ballistic Armor', Materials Research, 18(2), pp. 70-75. doi:10.1590/1516-1439.347514.

Damanik, F. S. (2007) Pengaruh kelembaban dan alkalisasi serat terhadap kekuatan geser komposit rami-poliester. ITB.

Defroit, N. et. al. (2010) 'Assessment of the tensile properties of coir, bamboo and jute fibre', Compos. Pt. A-Appl. Sci. Manuf., 41(5), pp. 588-595.

Ge, W. et al. (2012) 'Tensile Properties Of Bamboo Units In Different Sizes', in Proceedings of the 55th International Convention of Society of Wood Science and Technology August 27-31, 2012 - Beijing, CHINA, pp. 1-12.

H.Judawisastra, H., Wibowo, U.A., Putratama, A. (2016) 'Karakteristik Sifat Tarik Serat Bambu Petung (Dendrocalamus asper)", in Proc.', in Seminar Nasional Seminar Nasional Metalurgi dan Material (SENAMM) IX. Cilegon, West Java: ISSN: 2541-0725.

Hossen, M. F. (2011) 'Biocomposites reinforced with natural fibers 2000 - 2010', Progress in Polymer Science, 37(11), pp. 1552-1596.

Joshi, S. V., M. (2004) 'Are natural fiber composites environmentally superior to glass fiber reinforced composites?', Composites: Part A, 35, p. 371-376. 
Judawisastra, H., Sitohang, R. D. R. and Rosadi, M. S. (2017) 'Water absorption and tensile strength degradation of Petung bamboo (Dendrocalamus asper) fiber-reinforced polymeric composites', Materials Research Express. IOP Publishing, 4(9), p. aa8a0d. doi: 10.1088/2053-1591/aa8a0d.

Kalia, S; Kaith, B.; Kaur, I. (2009) 'Pretreatments of natural fibers and their application as reinforcing material in polymer composites-A review', Polym Eng Sci, 49, pp. 1253-1272. doi: 10.1002/pen.21328.

Kumar, K. K. (2017) Handbook of Composites from Renewable Materials, PhysicoChemical. 1st edn. New Jersey: Willey Scrivener Publishing.

Lu, T. et al. (2013) 'Composites: Part B Effect of surface modification of bamboo cellulose fibers on mechanical properties of cellulose / epoxy composites', Composites Part B, 51, pp. 28-34. doi: 10.1016/j. compositesb.2013.02.031.

Misra (2011) 'Bioplastics and Green Composites from Renewable Resources. Where we are and Future Directions.', in 18th International Conference on Composite Materials. Jeju Island, Korea: Elsevier.

Nozari, O. et al. (2013) 'Mechanical Properties and Water Uptake of Nanoclay / Wood Flour / LDPE Composites After Fiber Surface Mercerization', Cellulose Chemistry and Technology, 47(3-4), pp. 295-301.

Osorio, L. et al. (2011) 'Morphological aspects and mechanical properties of single bamboo fibers andflexural characterization ofbamboo/ epoxy composites', Journal of Reinforced Plastics and Composites, 30(5), pp. 396408. doi: 10.1177/0731684410397683.

Oushabi, A. et al. (2017) 'The effect of alkali treatment on mechanical, morphological and thermal properties of date palm fibers ( DPFs ): Study of the interface of DPF e Polyurethane composite', South African Journal of Chemical Engineering. Elsevier Ltd, 23, pp. 116-123. doi: 10.1016/j. sajce.2017.04.005

Peng, X. et. al (2010) 'Laccase and alkali treatments of cellulose fibre: Surface lignin and its influences on fibre surface properties and interfacial behaviour of sisal fibre/ phenolic resin composites.', Composites Part A, 41(12), pp. 1848-1856.

Refiadi, G. and Judawisastra, H. (2013) 'Optimasi Produk Komposit Polimer Vacuum Assisted Resin Infusion (VARI) menggunakan Metode Taguchi', Jurnal Teknologi Bahan dan Barang Teknik, 3(2), pp. 69-76.
Sugesty, S., et. al (2014) 'Bamboo as raw materials for dissolving pulp with environmental friendly technology for rayon fiber. on Chemistry', in 3rd International Seminar Department of Chemistry, Faculty of Mathematics and Natural Sciences. Padjadjaran University, pp. 194-199.

Thakur, Vijay Kumar; Thakur,Manju Kumari; Kessler, M. R. (ed.) (2014) Handbook of Composites from Renewable Materials, Vol.4 Functionalization. Willey.

Trujillo, E. et al. (2012) 'Weibull statistics of bamboo fibre bundles: methodology for tensile testing of natural fibres', in European Conference on Composite Materials. Venice, Italy.

Viel. Q (2013) Interface properties of bio-based composites of polylactic acid and bamboo fibers. Available at: https://www.google.com/l? $\mathrm{sa}=\mathrm{t} \& \mathrm{rct}=\mathrm{j} \& \mathrm{q}=\&$ esrc $=\mathrm{s} \&$ source $=$ web $\& \mathrm{~cd}=1$ $\&$ cad $=$ rja\&uact $=8 \&$ ved $=0$ ahUKEwiq 1 bCOv ZnbAhVFU30KHUcIAqwQFggnMAA\&url= https $\% 3 \mathrm{~A} \% 2 \mathrm{~F} \% 2 \mathrm{Fdigitalcommons.unl.edu} \%$ 2Fmechengdiss \%2F56\%2F\&usg=AOvVaw09 UIXWDfT4wQOOEcqzDzPA.

Vuure, A. W. van and Osorio, L. (2013) 'Long Bamboo Fibre Composites', in $18 T H$ INTERNATIONAL CONFERENCE ON COMPOSITE MATERIALS, p. 25.

Wang, X., Keplinger, T., Gierlinger, N., Burgert, I. (2014) 'Plant material features responsible for bamboo's excellent mechanical performance: a comparison of tensile properties of bamboo and spruce at the tissue, fibre and cell wall levels', Annals of Botany, 114(8), pp. 1627-1635.

Wang, F., Zhou, S. and Yang, M. (2017) 'Enhancing the morphological and mechanical properties of bamboo fibers', Plastic Research Online, pp. 14-16. doi: 10.3390/polym6123005.

Wong, K. J., Yousif, B. F. and Low, K. O. (2016) 'The effect of alkali treatment on the interfacial adhesion of bamboo fiber', $J$ Mater Des Appl, 224, pp. 139-148.

Yan, Libo; Chow, Nawawi; Yuan, X. (2012) 'Improving the mechanical properties of natural fiber fabric reinforced epoxy composites by alkali treatment', Journal of Reinforced Plastics and Composites, 31(6), pp. 425-437.

Yeasmin, Lucina., Md. Nasim Ali, Saikat, Gantait., Chakraborty, S. (2015) 'Bamboo: an overview on its genetic diversity and characterization', 3 Biotech, 5(1), pp. 1-11. doi: 10.1007/s13205-014-0201-5.

Zhang, X., Wang, F. and Keer, L. M. (2015) 'Influence of surface modification on the microstructure and thermo-mechanical properties of bamboo fibers', Materials, 8, pp. 6597-6608. doi: 10.3390/ma8105327. 